\title{
A Local Gap in Sustainable Food Procurement: Organic Vegetables in Berlin's School Meals
}

\author{
Charis Linda Braun ${ }^{1,2, *}$, Meike Rombach ${ }^{1}$, Anna Maria Häring ${ }^{2}$ and Vera Bitsch ${ }^{1} \mathbb{C}$ \\ 1 Chair of Economics of Horticulture and Landscaping, School of Management and School of Life Sciences \\ Weihenstephan, Technical University of Munich, Alte Akademie 16, 85354 Freising, Germany; \\ meike.rombach@tum.de (M.R.); bitsch@tum.de (V.B.) \\ 2 Unit of Policy and Markets in the Agri-Food-Sector, University for Sustainable Development Eberswalde, \\ Schicklerstr. 5, 16225 Eberswalde, Germany; anna.haering@hnee.de \\ * Correspondence: charis.braun@tum.de; Tel.: +49-03334-657-319
}

Received: 21 October 2018; Accepted: 15 November 2018; Published: 17 November 2018

check for updates

\begin{abstract}
Organic and local food plays an important role in the discussion of sustainable public procurement for school catering services. The present study investigates the value chain supplying school catering with organic produce, using the organic vegetable industry in the Berlin-Brandenburg region in Germany as an example. The qualitative case study employs a structuration theory approach to explore value chain actors' perspectives and their practices. Data is collected by conducting 14 in-depth interviews with actors on different supply chain levels (farming, wholesale, and catering) and analyzed by means of qualitative content analysis. The results suggest that, while organic food is generally important in school catering in Berlin, locally produced organic vegetables play only a minor role. A constraining factor is the lack of incentives for the use of locally produced organic food in the procurement guidelines, combined with a very limited budget for sourcing. Also, there are no preprocessing facilities in the region, while work organization in school catering services depends heavily on preprocessed food. From a farmers' perspective, focusing on process grade vegetables is rarely a common marketing strategy.
\end{abstract}

Keywords: sustainable public procurement; school catering services; agri-food value chains; structuration theory

\section{Introduction}

Organic and local food plays an important role in the discussion of sustainable school catering systems. With the European Union's move towards green public procurement, a number of regions across Europe have introduced public procurement policies that prioritize the use of organic food in school meals [1-3]. Some regions also include public procurement criteria that support the local sourcing of food [4]. Sustainable procurement policies that prioritize local and organic foods aim to support public health and food literacy, preserving the environment, and stimulating local economies $[4,5]$. Due to differences in national policy, food cultures, and school food systems, the concrete implementation of sustainable procurement practices varies greatly between European countries as well as between regions within countries $[1,6]$.

In Berlin, public primary and secondary all-day schools, which were attended by about 175,000 students in 2016 [7], serve hot meals at lunch time. However, as school lunch is optional in some schools, not all students eat at school. The school meals have a fixed price of EUR 3.25 and are payed for by parents, as well as subsidized by the city of Berlin. Meals are generally provided by private catering services on contracts that are awarded in individual per-school tendering processes for about four-year terms [8]. 
The city state of Berlin is one of the German pioneer regions striving to make its procurement practices for school catering more sustainable [1]. In 2014, Berlin's senate introduced the procurement policy for school catering which defined a set of compulsory sustainability criteria and a system of additional incentives for school caterers to improve the general quality of school meals. The compulsory criteria require the use of a minimum percentage of organic produce and include a range of other sustainability measures, such as a ban on genetically modified food and guidelines for waste reduction and recycling. Also, by combining additional quality incentives with a fixed price per meal, Berlin's procurement policy aims to create a situation where school caterers compete on the basis of quality rather than price [9]. The procurement policy incentivizes school caterers to increase the share of organic food beyond the mandatory percentage, amongst other aspects [8]. However, neither the compulsory criteria nor the additional incentives explicitly mention the use of local produce.

The present study investigates how the current procurement policy supports the local food sector, using organic vegetable value chains as an example. It builds upon the discussion on local value chains in school catering procurement and explores the perspectives of the actors in the value chain using a structuration theory approach $[10,11]$. By studying the value chain as a social system, it aims to identify value chain actors' practices as well as the structural factors that constrain or enable the local value chain. The study will help policy-makers, practitioners, and other stakeholders to understand the opportunities and challenges posed by using local organic produce in school catering. Food that is considered local in the present paper is produced in the federal state of Brandenburg that surrounds the city of Berlin, a region largely dominated by agriculture.

\section{Local Food Value Chains in School Catering}

Local sourcing of food for use in public institutions is an important issue in the discussion around sustainable procurement in school catering. One argument is that sourcing food locally can support local economies, reduce the environmental impact of food transport, and provide educational opportunities [5]. It is important to note, however, that local food systems are not by default more sustainable than national or global food systems [12]. Rather, the sustainability of public procurement practices depends on many factors, including production methods, use of resources, engagement with local communities, etc. $[5,13]$. In spite of some criticism, local agri-food value chains have the potential to contribute to sustainable food systems and are commonly discussed in the context of sustainable procurement policies, often in combination with organic production [4,13-16].

An agri-food value chain is a strategic partnership among interdependent businesses-such as farms, processing companies, and intermediaries-who work together to jointly create added value. To describe the level of value chain organization and partnership between firms in agri-food value chains, Peterson, Wysocki, \& Harsh [17] define a continuum from low intensity, 'invisible hand' coordination (spot markets) to high intensity, 'managed' coordination (vertical integration). Several researchers have examined alternative approaches to organizing agri-food value chains for school catering. The most cited examples are farm-to-school programs, which aim to increase the share of locally produced food in school lunches in the USA by connecting food producers directly with schools in a collaborative program [18]. Local school catering value chains are commonly described using concepts such as short food supply chains and values-based supply chains, e.g., [15,19-21]:

- Marsden, Banks, \& Bristow [22] define short food supply chain as an umbrella term for value chains that are characterized by 'relations of proximity' between the producer and the consumer. This can mean that there is face-to-face interaction between producer and consumer, or as in the case of local school catering, that food is sold in the region where it was produced and consumers are aware of the origin of the product [22,23]. The concept is commonly used to describe alternatives to long and complex chains that have a large number of intermediaries and diminish the proportion of total added value that remains with the original producers or within the region $[22,23]$. 
- The concept of values-based supply chains places emphasis on both the values associated with differentiated food products and the values that characterize the relationships between value chain actors [24]. Values-based supply chains are characterized by product differentiation (e.g., through social and environmental values embedded in products), as well as by partnerships, trust, shared governance, and a common commitment to the welfare of all participants [24,25]. Values-based supply chains may comprise strategic partnerships of midscale farms and other food enterprises that aim to handle high volumes of differentiated products, operate effectively on a regional level, and distribute their profits equitably between partnering companies [26].

In the present study, the concepts described above are used to explore and describe collaborations between actors at different levels in the local agri-food value chain for organic vegetables in school catering.

\section{Value Chains as Social Systems}

The present study uses a structuration theory approach to investigate an agri-food chain as a social system of value chain actors that interact with one other. Structuration theory is a social theory originally developed by Giddens [10] to describe and analyze the interdependence between structure and agency in social systems. A core tenet of structuration theory is the duality of structure, which describes how agency, in the form of social practices, shapes the structures within a system while the structures enable and constrain these same practices. Actors create and reproduce the structures within a system through social practices, across repeated interaction with one other. Structuration happens in a recurrent process: actors form an understanding of the system around them, draw upon rules that define what they can and cannot do, and use resources to control and influence their surroundings. In the context of the value chain, examples of resources are access to logistics and infrastructure, as well as the availability of a certain quantity of a product at a given time and place. Examples of rules are certification or procurement rules, but also non-formal norms, such as the way value chain actors interact with one other.

While structuration theory has been used in a large number of studies, ranging from sociology and information systems to value chain research, it has not gone without criticism. For instance, Giddens [10] has been criticized for conflating agency and structure [27], for not clearly defining his central concept of rules [11,28], and for an overly simplified dependency on the concept of rules in his notion of signification and legitimation [11,29]. Also, its highly abstract nature and lack of clear guidelines regarding its empirical application can make it difficult to use structuration theory in empirical research, e.g., [29,30].

To overcome the potential weaknesses of structuration theory, the present study uses Stones' refined structuration framework, which he calls "strong structuration theory" [11]. Stones [11] builds on the criticism described above and provides a re-interpretation of Structuration Theory as a methodologically sound approach to empirical research. It adds clear guidelines for the application of structuration theory and places emphasis on the analysis of the context from the actors' perspectives (actors' conduct analysis) and their understanding of the structures that define their actions (context analysis). The framework expands Giddens' original structuration concept with four analytically separate but interlinked components that can be studied empirically by focusing on each actor individually [11]:

- External structures are the actors' context. They include all conditions of action that exist independently of the actors.

- Internal structures describe what the actors know and how they think. This includes the actors' values and attitudes as well as their understanding of the context.

- Practices describe how actors draw on internal structures to interact within their context.

- Outcomes describe how both external and internal structures are produced and reproduced by actors' practices. 
The present study applies a structuration theory approach that investigates the value chain as a social system. The system includes actors at different levels of the value chain, such as farmers, wholesalers, and school caterers, as well as structural factors and practices within the value chain (Figure 1). It describes how practices by value chain actors (1) shape the structures within the system of the value chain while the structures (2) enable and constrain these same practices.

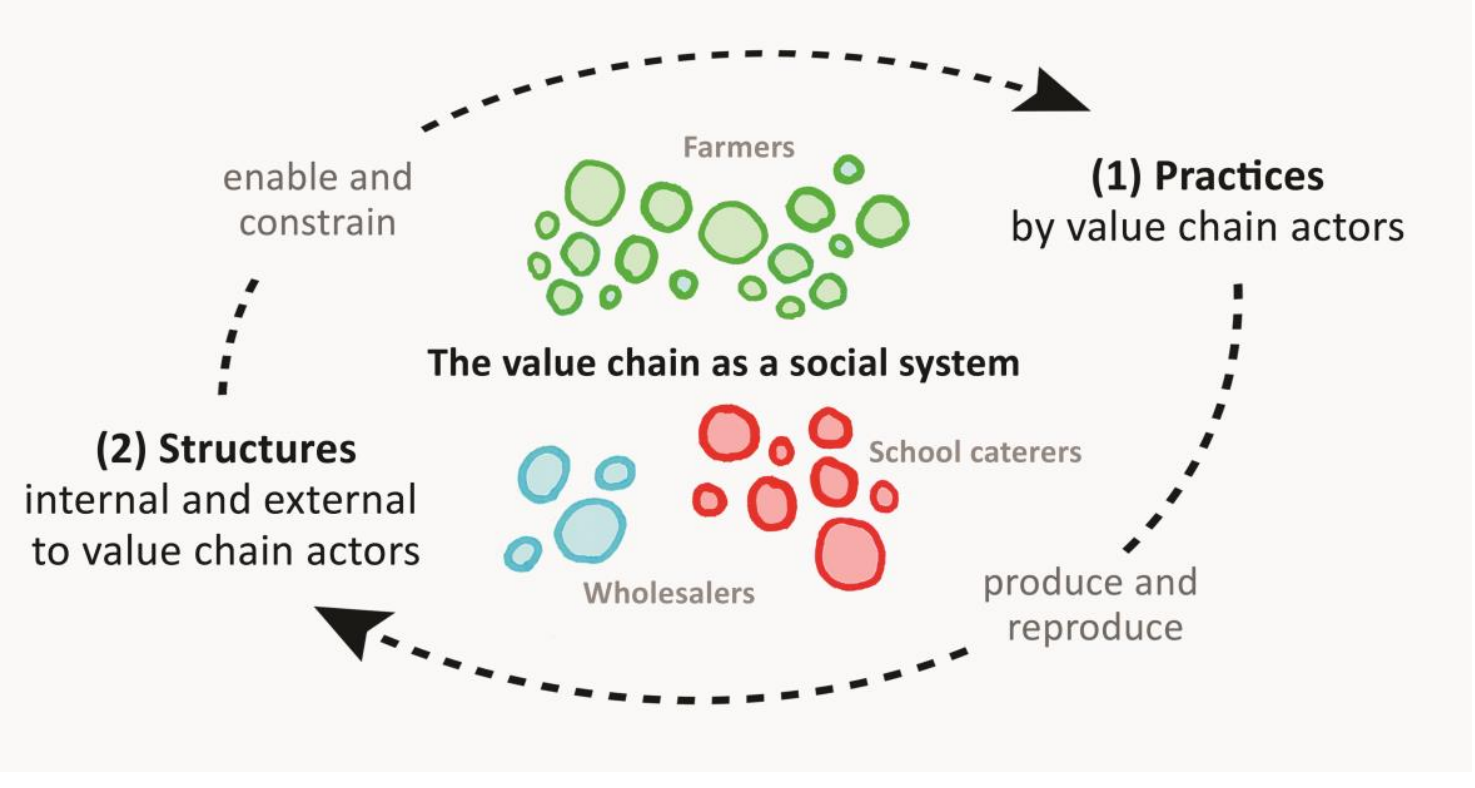

Figure 1. Structuration theory $[10,11]$, applied to the value chain for school catering.

A number of studies have relied on Structuration Theory for organizational and management research (e.g., [30-33]), supply chain research [34], and more recently, agri-food value chain research $[21,35,36]$. Heiss et al. [21] investigated the organization of a farm-to-school initiative using a structuration theory approach in a qualitative case study. The study explored organizational structure and practices as well as factors that help or hinder organizing efforts. Heiss et al. [21] used Giddens' [10] structuration theory to explore how farm-to-school actors create, maintain, or change organizational structures within a farm-to-school initiative. They concluded that, while structuration theory has yet to be adopted by researchers studying local food systems and value chains, it has much to contribute to studying the ways in which physical and social practices evolve into routine value chain systems [21].

Pullman \& Dillard [36] used structuration theory in their case study research into sustainability practices of a farmer's cooperative in the USA. Their qualitative case study examined the transfer of values and norms of family-owned farms into a values-based supply chain management system [36], and later the introduction of a new sustainability management tool [35]. Pullman \& Dillard [36] based their theoretical framework on structuration theory as formulated by Giddens [10], and refined by Sewell [29] and Stones [11]. They suggested that structuration theory can be used as a "theoretical lens" for investigating complex relationships among value chain actors see also [34,36], particularly in research that takes emergent value chain structures and the unique values of sustainable organizations into account [36].

An alternative concept that has been used in agri-food chain research is the actor-network theory, e.g., [37,38]. It is similar to strong structuration theory in that it comprises a theoretical and methodological approach to analyzing complex systems. Actor-network theory is commonly used in the study of systems that consist of technology and human actors. It offers a different notion of the relationship between actors and systems to the one held by structuration theory, and it has been criticized for ignoring human motives and virtues [39,40]. Jack \& Kholeif [41] argue that strong structuration theory is as robust and credible as actor-network theory, while also being particularly 
useful for case studies that deal with clusters of actors within systems and their relationships with one other, as is the case for agri-food value chains. Hence, the present study relies on strong structuration theory according to Stones [11].

In order to broaden the understanding of the value chain as a complex system of actors and value chain practices, the present study uses the four analytical components of strong structuration theory (practices, internal structures, external structures, and outcomes). The study also follows Stones' [11] iterative analysis process to explore each actor's value chain activities and their individual perspectives, values and attitudes (actors' conduct analysis). Enabling and constraining factors were derived (context analysis) on this basis.

\section{Methods}

The present study used a qualitative case study approach to explore the local organic vegetable value chain in the Berlin-Brandenburg metropolitan region in the context of Berlin's procurement policy. The use of the case study approach as a research strategy aims at understanding the dynamics of a single setting [42]. As procurement practices for school meals differ considerably between countries and regions within countries, and because Berlin is a pioneer region in the use of organic food in school catering in Germany [1], the study focuses on a unique phenomenon. Thus, it is investigated as a single case study [43].

For the field of agribusiness, case study research has been deemed appropriate and successfully applied [44-46]. Moreover, case study approaches are commonly employed in research that builds upon structuration theory, which includes agri-food value chain research [21,30,35,36]. Strong structuration theory is particularly suited to case study research in management and organizational studies, as it combines theory with a disciplined methodological approach to empirical research into the relationships between actors and their context [41]. In the present study, the case study approach helps to gain an in-depth understanding of the case through the perspectives and practices of value chain actors. These include school caterers, wholesalers, and organic vegetable famers based in the Berlin-Brandenburg region. It was not possible to identify vegetable pre-processing facilities for organic catering within the region. The present study focuses on sourcing and distribution practices for organic vegetables. End consumers, students and parents, were not considered for the study. The composition of school meals is decided by school caterers based on agreements made during the tendering process.

\subsection{Data Collection}

School catering value chains are complex systems in which several structural factors and the interaction between a large number of participants define value chain practices [19,21]. Potential interviewees were identified based on online research, conversations with value chain actors, and information provided by local non-governmental organizations that are active in the fields of school catering and organic farming.

To capture multiple perspectives on the case, document its many facets, and identify common value chain practices, the present study used maximum variation as a purposeful sampling strategy [47]. Interviewees were selected from each level of the value chain and within each value chain level. The selection aimed to include interviewees from companies with a diverse range of characteristics, such as different distribution channels or company sizes. Interviewees were actors in management positions who were expected to be knowledgeable about the phenomena. This included farm owners and managers in organic vegetable production, as well as managers working in wholesale and catering (Table 1).

Data was collected through fourteen in-depth interviews that served to obtain a detailed and comprehensive representation of the value chain. In-depth interviews are used to seek exhaustive information and a thorough understanding of the issue [48], as well as gather rich data about actors' perceived realities and day-to-day practices [49]. The interviews were conducted in person between 
November 2017 and May 2018, and each interview lasted 60 to 90 min. To guide data collection, semi-structured interview guides were used. For each level of the supply chain, there was a specific set of questions.

Table 1. Interviewees and their backgrounds.

\begin{tabular}{|c|c|c|c|}
\hline & Interviewee & Characteristics & Size \\
\hline Farmer 1 & Owner & Distribution through direct marketing & 1 ha \\
\hline Farmer 2 & Owner & Distribution through organic wholesale & 5 ha \\
\hline Farmer 3 & Owner & $\begin{array}{l}\text { Distribution through direct marketing and } \\
\text { organic wholesale }\end{array}$ & 13 ha \\
\hline Farmer 4 & Production manger & $\begin{array}{l}\text { Distribution through direct marketing and } \\
\text { organic wholesale }\end{array}$ & 20 ha \\
\hline Farmer 5 & Owner & $\begin{array}{l}\text { Distribution through direct marketing and } \\
\text { organic wholesale }\end{array}$ & 25 ha \\
\hline Wholesaler 1 & Managing director & Organic vegetables wholesaler & 3 employees \\
\hline Wholesaler 2 & Managing director & Full-range organic food wholesaler & 50 employees \\
\hline Wholesaler 3 & Managing director & Full-range food wholesaler & 250 employees \\
\hline Caterer 1 & Owner & $100 \%$ organic $*$, operating in Berlin & 900 meals/day \\
\hline Caterer 2 & Owner & $100 \%$ organic $*$, operating in Berlin & 1000 meals/day \\
\hline Caterer 3 & Kitchen manager & $100 \%$ organic $*$, operating in Berlin & 1200 meals/day \\
\hline Caterer 4 & Kitchen manager & $56 \%$ organic $*$, operating in Berlin & 7000 meals/day \\
\hline Caterer 5 & Procurement manager & $\begin{array}{l}40 \% \text { organic*, operating in Berlin } \\
\text { and Brandenburg }\end{array}$ & 30,000 meals/day \\
\hline Caterer 6 & $\begin{array}{l}\text { Department manager for } \\
\text { catering services }\end{array}$ & $\begin{array}{l}40 \% \text { organic } * \text {, operating nationwide, } \\
\text { centralized procurement }\end{array}$ & 40,000 meals/day \\
\hline
\end{tabular}

* Share of organic food in school meals, by value. The Berlin school catering procurement policy does not specify the product group in which the organic ingredients must be used.

The interview guides covered the following information:

- Introduction: The interviewee's background and details about their company.

- Perspectives on value chain practices: Relevant actors and their interaction within the value chain focusing on the production, distribution, and procurement of organic vegetables.

- Perspectives on the organic vegetable industry: Recent market developments focusing on the Berlin school catering procurement policy.

- Wrap up: The opportunity for interviewees to add and ask questions.

The topics were addressed using open-ended questions that were asked based on the flow of the conversation. During the interview, participants were also asked to draw a sketch of the value chain and to explain it. This activity aimed to generate deeper insight into each actor's perception of the value chain. Conducting drawing activities with participants in qualitative organizational research is a method suggested by Warren [50] as a tool for improving participant involvement and for generating an increased understanding.

\subsection{Data Analysis}

The interview material was prepared as the first step in data analysis. Twelve of the fourteen interviews were audio-recorded and transcribed verbatim using the f 4 transcription software (dr. dresing \& pehl GmbH, Marburg, Germany). Two interviewees did not consent to being recorded, field notes were therefore created. In qualitative research, it is common to use a form of transcription to prepare the interview data for analysis [51]. As in the present study, the content of the interviews is what's interesting, the personal speech characteristics were removed (e.g., dialects, pauses, filler words). In the next step, the transcriptions and field notes were analyzed using qualitative content 
analysis. The latter is a method used to systematically reduce and summarize qualitative data by assigning text fragments to categories that are defined in a coding frame [52]. In the data analysis, the qualitative content analysis software ATLAS.ti (ATLAS.ti Scientific Software DevelopmentGmbH, Berlin, Germany) was used, which supports the development of the coding frame, category assignment, and category management and their relationships [53].

The interview data was structured using a hybrid approach of deductive and inductive coding [52]. The main categories were defined deductively based on the analytical components of strong structuration theory: practices, internal structures, external structures, and outcomes (Figure 2). Following the iterative analysis process defined by Stones [11], subcategories were defined inductively in a recurrent series of steps. First, practices and internal structures were identified for each actor. This included the actors' value chain activities and their perspectives on the phenomenon as well as their values and attitudes. In another step, the context analysis, relevant external structures were identified. Based upon the external structures, constraining and enabling factors were derived. The categories and subcategories were defined and described in ATLAS.ti.

\section{Individual actors' conduct analysis}

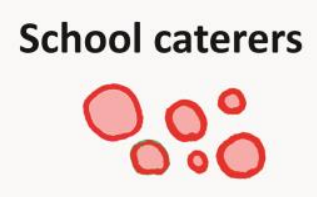

internal structures

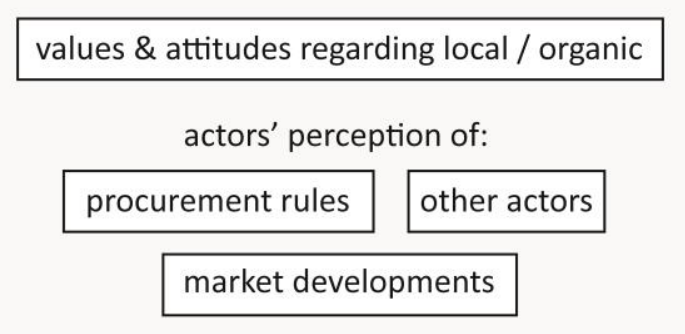

Wholesalers

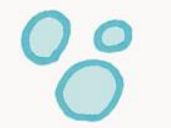

Farmers

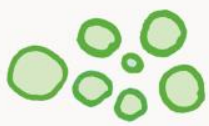

\section{value chain practices}

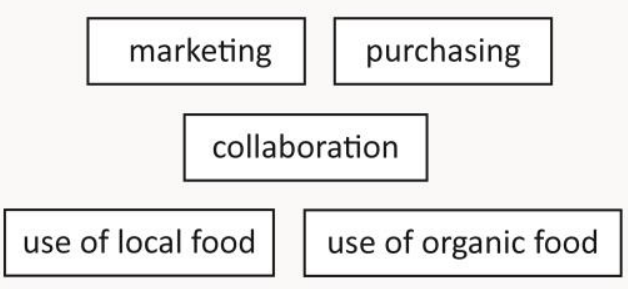

Context analysis

External structures and outcomes

enabling and constraining factors for a local value chain

\begin{tabular}{|c|c|}
\hline demand for local food & supply of local organic food \\
\hline procurement criteria & actors' attitude regarding local / organic \\
\hline
\end{tabular}

Figure 2. Coding frame: hybrid approach based on strong structuration theory. 


\section{Results und Discussion}

Strong structuration theory reveals structural factors that influence value chains based on the analysis of value chain practices and actors' internal structures. The following sections present practices and internal structures broken down by value chain level. Based on these findings and the body of literature reviewed above, the second part discusses the structural factors that enable and constrain the use of local organic vegetables in Berlin school meals.

The participants in the present case study are school caterers, wholesalers, and organic vegetable farmers located in the Berlin-Brandenburg metropolitan region. Preprocessing facilities for organic vegetables could not be identified within the region (Figure 3).

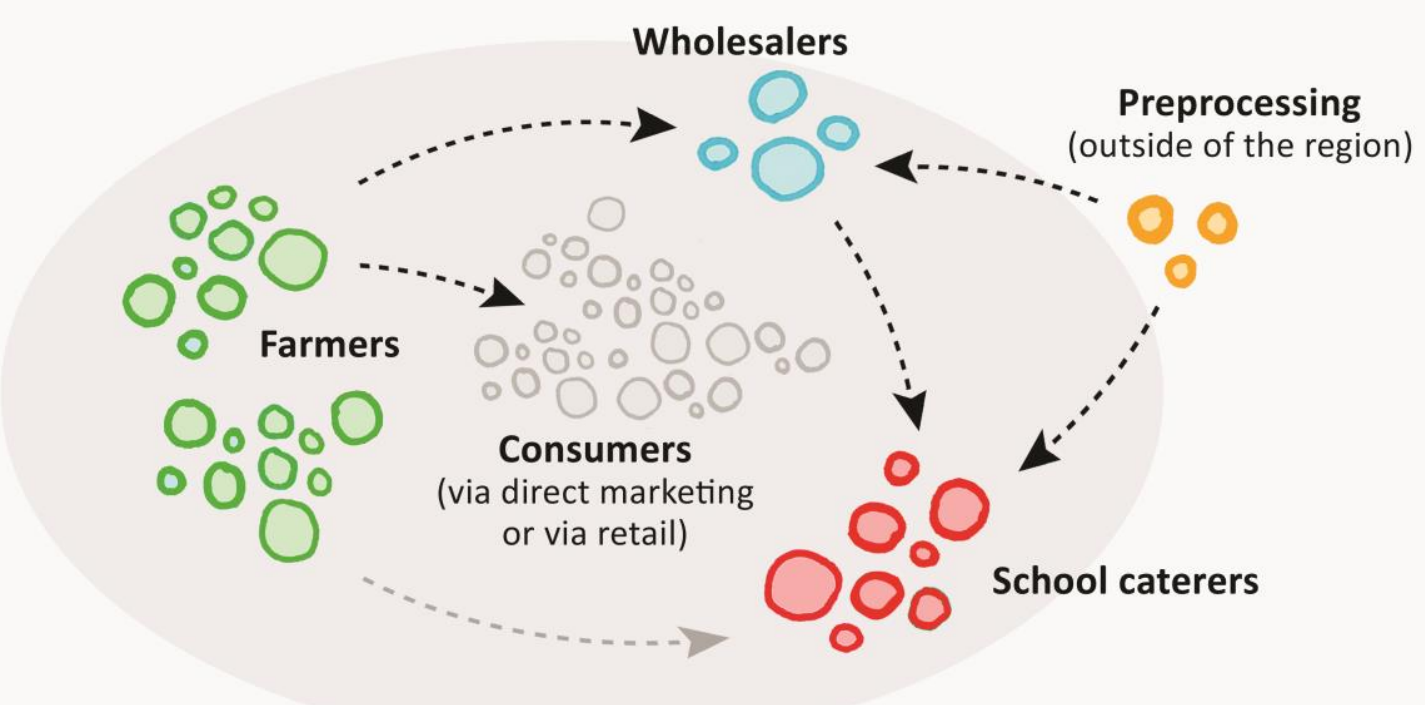

Figure 3. Actors' sourcing and distribution practices in the organic vegetable value chain in the Berlin-Brandenburg region.

\subsection{Value Chain Actors' Conduct: Internal Structures and Practices}

Caterers-In Berlin, school catering is handled by private catering companies. The interviewed caterers range from large companies that prepare tens of thousands of meals per day to smaller companies that prepare several hundred meals per day. The caterers specialize in school meals and run their own large-scale kitchens from which they supply schools with food. Only two of the interviewed school caterers run kitchens are actually located at a school.

Public schools select a catering company through an individual tendering process based on Berlin's rules for school catering procurement. The rules define a set of compulsory award criteria and a graded scoring system of additional incentives for school caterers to improve the general quality of school meals. Among other aspects, the compulsory criteria require the use of a minimum percentage of $15 \%$ of organic ingredients while the scoring system incentivizes school caterers to increase the share of organic food beyond what is mandatory [8]. It does not specify the product group in which the organic ingredients must be used.

The Berlin procurement rules for school catering are perceived by interviewees as a strong driver for the use of organic food. As organic food is one of the explicit reward criteria in the scoring system, catering companies compete over the share of organic food they use. A kitchen manager of a school catering company described his company's motivation to increase the share of organic food: 
We use organic food because we got our school catering contracts through tenders. There are certain tendering criteria and the catering companies can offer a percentage of organic food [which they guarantee to they will use], which is equivalent to a certain number of points in the tendering process, so you are more likely to be awarded the contract. There are a maximum number of points to be awarded for an organic share of $56 \%$, and that's what we offered. So the school meals we provide use $56 \%$ organic ingredients. (Caterer 4: kitchen manager, 7000 meals per day)

While a few caterers had focused on organic food before the procurement rules were introduced, the incentives for using organic food have also led other catering companies to increase the share of organic food on their menus. All interviewed caterers confirmed that, at the time of the interview, at least $40 \%$ of the total food they used for school meals was organic, expressed in terms of value. The graded scoring system incentivizes the use of organic food up to $56 \%$, which is what caterers aim for when they try to win a tender. Aiming for a smaller organic percentage makes it easier to source ingredients, particularly for some large caterers who regularly need large quantities of produce to fulfill their contracts. Larger caterers also said that they primarily use organic ingredients in product groups where the price difference between organic and conventional products is small. Some smaller caterers use up to $100 \%$ of organic ingredients because they operate in a niche market segment that also serves institutions that particularly value organic food, are able to pay higher prices, and are not subject to the procurement policy, such as independent schools and nurseries.

The use of locally produced food is not incentivized by Berlin's procurement policy, unlike the sustainable procurement practices in other European regions [4]. When local food is used, this is due to a positive attitude shown towards local sourcing by some caterers, and, to a certain degree, explicit requests from parents:

It's parents, of course, who ask for local food. Local sourcing, that's one thing that's always requested. And I tell them we'll do our best. But in the end, as I said, our main supplier is [local organic wholesaler] and we can only buy what [local organic wholesaler] has to offer in terms of local food. (Caterer 1: owner of catering company, 900 meals per day)

The last statement indicates that, in practice, the use of local organic food depends on availability through the caterers' regular suppliers. Caterers describe a general need to balance several factors in their sourcing practices. Other factors that influence the use of local organic food are price, quality, and the availability of preprocessed food, such as peeled and sliced potatoes, on which they are heavily dependent. Two of the actors interviewed described their perspectives on sourcing as follows:

In general, this is a very important concept for us. Using a lot of organic vegetables, whenever possible fresh and local-because we want to provide healthy meals. But, of course, we also need to make compromises [ ... ], for example, beans in winter and, of course, canned tomatoes and canned corn and preprocessed sauerkraut. And sometimes preprocessed potatoes, which we know are not from the region. [...] My cooks don't have time to peel potatoes for eight hours. We don't have the capacity and then we need to use that [preprocessed] stuff. (Caterer 2: owner of a catering company, 1000 meals per day)

We always tell our suppliers that we want it [local and seasonal produce] whenever possible. The determining factors are (a) [pre-processed] qualities and (b) price. It is that simple. (Caterer 4: kitchen manager, 7000 meals per day)

As several studies have shown, a key constraint in sustainable school catering procurement is the price premium for local or organic produce, e.g., $[15,54]$. With regards to the situation in Berlin, the interviewees perceived the fixed price of 3.25 EUR per meal as a limiting factor to using a significant share of local organic food, which the caterers described as more expensive than conventionally sourced or non-regional organic foods. Price is described as a decisive factor in the decision between purchasing local or non-local produce: 
Of course, you have to remember that we are in a very low-price segment. A school meal costs about EUR 3.25 and of that, we can use a maximum of EUR 1 for the cost of goods. [ ... ] We have committed ourselves to using organic, so we do. But if, for example, an organic apple from Germany is twice as expensive as one from Spain, we take the Spanish one. (Caterer 5: procurement manager, 30,000 meals per day)

The interviewed caterers purchase organic vegetables from local conventional and organic wholesalers as well as from specialized preprocessing and trading companies that operate nationwide. An important factor in selecting a supplier is reliable deliveries tailored to the workflow of large-scale kitchens, which a caterer describes as follows:

Delivery reliability is very important for us. We need to make sure we get what we ordered. We plan in advance. We do plan our menus and we need to follow he plan. If it doesn't work out once, that won't be the end of the world, but in general, we need to follow the menu plan. And we rely on getting what we order [...] so we have two different wholesalers that supply us with peeled potatoes, organic and conventionally produced. (Caterer 1: owner of a catering company, 900 meals per day)

This statement also underlines large-scale kitchens' dependency on a continuous supply with large quantities of certain foods. Therefore, larger catering companies commonly coordinate requirements with their suppliers ahead of time, and make arrangements to ensure delivery reliability for specific products:

We have an arrangement with our suppliers that if we need peeled potatoes, we can call them until noon and they will deliver the goods the next day. This is really important with regards to shelf life, ordering processes, and the logistics involved-and that's why we have a fixed supplier. Because we do not have large storage capacities in our kitchens, we have to be able to rely on the supplier being really flexible so that we can order often-sometimes on a daily basis. (Caterer 5: procurement manager, 30,000 meals per day)

While all interviewed caterers purchase mainly from wholesalers, direct purchases from local farms are rare and only reported by smaller catering companies. Such purchases were described as "one-off deliveries". Individual farms cannot regularly provide the foods and the reliable service required in school catering. Also, sourcing from farms means less delivery security and additional organizational effort, such as individual ordering and delivery arrangements:

If I always purchased directly from farmers, there would be a lot of effort needed for coordination and there's also the risk that their car breaks down or that something else goes wrong [...] and I'd be stuck here alone with no vegetables. (Caterer 1: owner of a catering company, 900 meals per day)

The above statement illustrates the crucial role that local intermediaries play in school catering procurement for the access to local and organic foods through bundling supply and providing logistics see also [55].

Wholesalers-The interviewed wholesale managers represent three different companies: a full-range wholesaler focusing primarily on conventionally produced food but also offering a range of organic products, an organic wholesaler specializing in organic food, and a new, specialized organic vegetable wholesaler aiming to reduce food waste by distributing farms' surplus vegetables to catering services. All three wholesalers operate within the Berlin-Brandenburg metropolitan region.

All three interviewees perceived a generally increased demand in local and organic food, both from retail and catering. The organic wholesalers link this increased demand to the procurement rules in school catering:

Organic school catering is an important factor for organic wholesale in Berlin. On one hand, there are caterers who are committed to using organic food even without any guidelines-and 
have done so for a long time. On the other hand, the procurement guidelines encourage caterers who are not big fans of organic food to look into organic as well. This includes large companies that operate nationally and internationally. (Wholesaler 2: managing director, full-range organic food wholesaler)

Both the organic and the specialized vegetable wholesaler described a strong dispositional commitment to organic farming and local value creation that plays a central role in their local sourcing efforts. The organic wholesaler interviewed for this study perceives himself as deeply rooted in the local organic industry and has maintained long-standing partnerships with local farms:

In season, we source a large share [of vegetables] locally. This means from Berlin, Brandenburg, and the districts bordering Brandenburg. We definitely try to source from nearby. When it comes to local fruits and vegetables, local organic wholesalers are important because they have long-standing relationships with farmers. (Wholesaler 2: managing director, full-range organic food wholesaler)

The specialized vegetable wholesaler works with both local farmers and importers to rescue surplus harvest and non-marketable, imperfect vegetables and sell them to restaurants and caterers. They describe themselves as a mission-driven company that primarily aims to reduce food waste. The interviewee perceives it as difficult to build relationships with local farmers because for them, selling imperfect produce is often not interesting from an economic perspective due to the effort required for organization and logistics:

We thought, there are so many farmers-we just need to show them what we do and they will sign up. But that's not how it is. You need to adapt to the processes of farmers and it takes a long time to establish relationships [with farmers] in Brandenburg. (Wholesaler 1: managing director, organic vegetables wholesaler)

In contrast, the full-range wholesaler has no specific local sourcing practices for organic vegetables. The interviewees described past attempts to build direct relationships with local organic farms that were unsuccessful due to requirements that could not be met by farmers, such as a continuous supply of certain quantities and qualities. The full-range wholesaler sees business potential in trading local organic vegetables but does not currently work with local organic vegetable farms because access to the farms is perceived as difficult. This underscores the importance of the organic wholesale sector in the Berlin-Brandenburg region that actively works on establishing partnerships with local producers and connects rural farms to purchasers in urban areas.

Farmers-All interviewed farmers are based in Brandenburg, the federal state surrounding Berlin, and concentrate on growing organic vegetables. In Brandenburg, organic vegetable production spans about 790 hectares ( 400 hectares of potatoes and 390 hectares of other vegetables), which is a relatively small share of the total agricultural land compared to other parts of Germany [56]. The 390 hectares of organic vegetables represents $6 \%$ of total vegetable production in Brandenburg; in the neighboring federal state of Saxony this figure is $25 \%$ grown on 1000 hectares [56]. The interviewees include both managers of well-established and newly founded farms. They described a strong commitment to organic farming principles and personal values that play an important role in how they run their businesses, such as a commitment to family farming and biodiversity. In particular, newcomers express strong notions of independence and entrepreneurial daring in pursuing their individual ideas of starting up a farm while at the same time describing economic challenges that impact their value chain activities.

In our first year, we started out very idealistic, with a diversity of vegetables crops, direct marketing, and things like that. But at some point, we realized that it is so much work and just not worth it. [ ... ] since then, we have developed our business in such a way that we sell 90\% [through wholesale], which means specializing in specific vegetable crops. (Farmer 2: 5 ha, wholesale supplier) 
All interviewees perceived organic vegetable farmers in Brandenburg as each having an individual niche, which results in what interviewees describe as very little competition between farms. At the same time, they saw an increase in demand for local organic vegetables. One actor described a demand-driven market that is still undergoing further development. Several farmers emphasized that Berlin is a very important market for their products where they can charge "good prices", both in direct marketing and organic wholesale. Two farmers described this situation in the following statements:

If we weren't based here [near Berlin], it really would be much harder. That's just the way it is. We have the great advantage of being here. (Farmer 3: 13 ha, distribution through direct marketing and organic wholesale)

There could be more farms. There are still a lot of goods brought in from outside the region and I am not just talking about exotic fruit. Also things that we stock for January or February-onions, carrots, our supply only lasts for a certain time. Because there is so little vegetable production, so much more could be done, also with regards to storage. Demand is growing steadily. (Farmer 2: 5 ha, distribution through organic wholesale)

Despite the opportunities described above, farmers are also facing challenges. A drawback noted is the effort required for logistics, particularly for direct marketers:

Berlin is our main sales market, but the problem is that you need time to get there. If you start out growing vegetables, you don't have time for anything. You don't have time for a farmers' market and you don't have time to drive your produce to Berlin. It would take way too much time- - time that you need on your fields. That's why intermediaries who take your products to Berlin are so interesting. (Farmer 1: 1 ha, distribution through direct marketing)

The interviewed organic vegetable farmers market their products primarily within the Berlin-Brandenburg region as fresh produce, both through direct marketing, independent grocery stores, and local organic wholesale. Farms that focus on direct marketing sell their produce through farmers markets, box schemes, community-supported agriculture, or directly on site at their farms. Many newcomers focus on direct marketing because it enables them to market products quickly, independently, and flexibly, and to deal with challenges in the start-up phase that may prevent them from working with wholesalers. While some of the farmers interviewed had never heard of the Berlin procurement rules for school catering, others had experience with occasionally distributing surplus produce to caterers directly. Those transactions where described as individual sales:

In high season, I sometimes need to sell surplus produce [...]. So, if a catering company calls and asks what we have, I'll tell him, say, that we have oversized celery, for example. If he then takes 100 kilos of it, it may make sense to actually drive there [to deliver it]. (Farmer 5: 25 ha, distribution through direct marketing and organic wholesale)

Other farmers distribute their products through wholesalers. Interviewees described long-standing partnerships with local organic wholesalers that involve production planning and sharing market information. Well-established farms perceived this collaboration as reliable and the partners as trustworthy. They also described information sharing and joint pricing:

Our relationship with local wholesale is based on partnership. Once a year, they bring producers together to discuss prices and requirements. And they put local first. If a product is available locally, they will go to great lengths to source it locally. (Farmer 4: 20 ha, distribution through direct marketing and organic wholesale)

The interviewed farmers mostly have well-functioning local marketing channels for fresh produce, either using some form of direct marketing or working with local organic wholesalers (Figure 3). Conventional wholesale plays a minor role. Direct marketing to catering services is also rare. Similar to the caterers, the interviewed farmers also see a lack of organic processing facilities in the region see also [57]. 


\subsection{Context Analysis: Structural Factors}

The above analysis of individual actors' practices and internal structures provides a depiction of current marketing and procurement structures in Berlin school catering and the local organic vegetable industry. It suggests that the proliferation of organic food in school catering has not supported the creation of coordinated local value chains. When local organic vegetables are used in school meals, this happens largely by chance. Local organic vegetables only find their way into Berlin's school meals when caterers can use their regular suppliers to source locally and when prices for local produce are competitive. There is no apparent local end-to-end value chain from farm to school. The present study identified four key structural factors that enable or constrain the use of locally produced organic vegetables in Berlin school catering: (1) price, (2) procurement policy, (3) supply and demand for local organic produce, as well as (4) shared values and partnerships between actors.

Price-Among the interviewed caterers, there is a general understanding that the primary limiting factor for locally-sourced organic food in school catering is price. The fixed price of EUR 3.25 per meal is perceived as too low to use a significant amount of local organic food. These findings are in line with earlier studies from other regions that also identified higher prices for local or organic food as a constraining factor for their use in institutional catering, e.g., [15,21,54].

According to Filippini et al. [14] price is not a constraint for including organic food per se, but a limit to increasing the volume of organic food in school catering. Thus, they consider sustainable procurement policies as only partially successful in overcoming the strict cost effectiveness criteria of traditional procurement, a result which is in line with the findings of the present study. While school caterers in Berlin no longer compete directly based on price, they compete in terms of cost efficiency as they try to provide higher shares of organic food at the given price. This in turn prevents them from sourcing locally, which is often less cost-efficient due to small production scales and costly logistics see also $[16,54]$.

Lethinen [15] found higher prices for local food to be the primary barrier to the implementation of local school catering procurement when local food producers compete with supply from national or even international food markets. This is also true for the Berlin-Brandenburg region, where organic vegetable farms in Brandenburg focus on selling high-priced differentiated products through retail or direct marketing and do not usually aim to compete over price with food from national or international markets. In establishing local value chains for school catering, one challenge is to create a system that is financially viable and attractive for local organic farmers. Conner et al. [19] and Stevenson et al. [26] suggest that this could be achieved through establishing values-based supply chains, where farms form strategic partnerships with other value chain actors to produce and distribute high volumes of differentiated produce on a regional level, and distribute their profits equitably between partnering companies.

Procurement policy-Since the introduction of the current Berlin school catering procurement policy, both the organic wholesaler and the specialized vegetable wholesaler have seen an increase in the demand for organic food. These findings are in line with other studies that identified the implementation of procurement policies on a local level as a key driver for sustainable procurement practices $[4,14]$. However, the interviewed farmers did not perceive an increased demand for organic vegetables linked to the introduction of the procurement rules. This situation suggests that the increase in demand is satisfied by organic produce that is mostly produced outside the Berlin-Brandenburg metropolitan region. It can be seen as a result of the Berlin procurement rules not incentivizing the use of local food, which stands in contrast to other sustainable procurement policies that directly or indirectly prioritize local food [4,6]. Smith et al. [4] described examples from Scotland and Denmark where the prioritization of local sourcing in sustainable public sector food procurement is used as a policy instrument to support local economies and improve public health.

European procurement regulations are sometimes assumed to restrict the local sourcing of food for public institutions [15]. This is due to an inherent tension arising from several concerns that European public procurement policies aim to satisfy, ranging from environmental and social sustainability 
on the one side, to free trade, economic efficiency, and competition on the other [6,58]. The latter can be interpreted as prohibiting the prioritization of local producers in public catering contracts. Despite this apparent restriction, there is some scope for public authorities in the formulation of their specific procurement policies [58]. Local policy-makers take advantage of this scope to prioritize local food through quality criteria that are closely associated with local sourcing, such as freshness and seasonality [6].

Supply and demand for local vegetables-Independently of the procurement rules, interviewees at all value chain levels perceived an increased demand in locally produced food. Some caterers see this as a consumer trend which is also increasingly relevant in school catering. They describe a general interest in using more local organic food in school catering but also suggest that use in practice is restricted, due to price, but also due to a lack of preprocessed, locally produced supply.

The existing organic farms concentrate on marketing fresh produce through direct marketing and regional organic wholesalers rather than producing vegetables for processing. This is also due to a lack of preprocessing facilities in the Berlin-Brandenburg region. Because of work organization and facilities in large-scale kitchens, catering companies are heavily dependent on preprocessed food, such as peeled and sliced potatoes, which they cannot source locally. Instead, they rely on specialized suppliers that operate nationwide and partially use cheap, anonymous vegetables from spot markets, which makes it difficult for school caterers to track the origin of the primary products. This situation was confirmed by value chain actors on other levels of the value chain. It is also in line with findings from other studies that identified the dependency on preprocessed food as a barrier for local value chains in school catering $[18,54,59,60]$.

In contrast to findings from earlier studies in Northern Europe [16,61], the present study found no general issues with the availability of organic food for use in school catering. In Berlin, school caterers and wholesalers have established structures that enable them to source the required qualities and quantities from national and international providers.

Shared values and partnerships-Despite the issues described above, there is a positive attitude towards local sourcing and local organic food production that many of the interviewed actors share. Shared values among actors are considered to be key prerequisites for establishing short food supply chains or values-based supply chains $[23,24]$, which are discussed in the context of sustainable food systems, also with regards to school catering $[15,62]$. In addition to this, there are some current value chain practices that could already be characterized as using short food supply chain or values-based supply chain concepts. For example, several farms that use forms of direct marketing as distribution channels are embedded in structures that could be described as short food supply chains [22]. Other farms have long-standing, trustworthy wholesalers as partners that could also be characterized as coordinated values-based supply chains [26]. The existing local value chains, however, are not geared towards school catering.

Using Peterson's [17] categorization of agri-food chains, school catering procurement in Berlin can be characterized as mostly spot market-based with a tendency towards vertical coordination, particularly in the case of larger catering companies. Some caterers have long term arrangements and coordinate requirements with their suppliers in advance. Local organic wholesalers play a particularly important role in the industry, as they supply school caterers with organic vegetables and handle the logistics to make produce from Brandenburg available in Berlin. Some wholesalers have also adjusted their services and product range to the specific requirements of public caterers. The importance of regionally-based intermediaries has also been pointed out by Izumi et al. [55] who described food distributors and their relationships to local actors as enablers for local school catering value chains.

\section{Conclusions}

The present research applied strong structuration theory in a case study of the organic vegetable value chain for school catering in the Berlin-Brandenburg metropolitan region. By providing comprehensive insights into the social system of the value chain, the results contribute to the discussion 
on local and organic food in sustainable school catering, which is a current issue in many European regions. Using a strong structuration theory approach, it was found that the actor's existing practices prevent the formation of a complete value chain from farm to table. There is a local gap in school catering. While the current catering procurement policy has led to an increased use of organic food in Berlin's school meals, it has not contributed noticeably to local value creation in the organic vegetable industry. Without intervention which aims to support local value chains, the existing structures can be expected to continue to reproduce the local gap in sustainable procurement in Berlin's school catering.

There are several ways this situation could be addressed at the practical and policy levels. To establish sustainable school catering that includes locally-sourced organic produce, Berlin's policy-makers could support local value creation by introducing incentives for the use of local organic food in public procurement policies, by establishing award criteria that take local sourcing into account and support it financially. There are examples from other regions in Europe that have successfully integrated local sourcing incentives into public procurement guidelines see, e.g., [4]. Moreover, to evaluate the impact of procurement policy, an evaluation framework, including periodic data collection on school meals and the local vegetable industry, has to be developed. At present, there are no statistics available on the use and sourcing of organic food in school catering in the region, which also makes it difficult for both policy-makers and practitioners to make strategic decisions.

The city of Berlin has committed to implementing a comprehensive and long-term sustainable food policy. A further increase in the organic share of school catering is part of this policy [63]. The results of the present study suggest that, without an explicit focus on local sourcing as an award criterion in the procurement process those measures will not strengthen sustainable value creation in the region.

On a practical level, infrastructure problems in the processing of fresh vegetables have to be overcome in order to increase the use of local organic vegetables in Berlin's school meals. This could be addressed by equipping large-scale kitchens with the staff and facilities required to process fresh produce or by setting up pre-processing facilities in the region. Based on the current results, only the latter solution appears realistic, due to the decentralized nature of school catering in Berlin and the highly optimized work organization that generally prevails in school catering.

Policies to strengthen local organic production for schools need to provide more incentives for farmers in the region to grow vegetables for processing. Support needs to be provided to young and diversifying farms to introduce them to organic vegetable growing, produce the necessary qualities and quantities, and develop financially viable marketing strategies that are geared toward school catering services. Policy-makers and local non-governmental organizations could help to increase local organic vegetable production by providing support for farmers new to organic farming, for example by setting up and supporting training and advisory services for farmers in the region. Compared to other German regions, there are hardly any specific advisory services for organic vegetable producers in the Berlin-Brandenburg region.

Practitioners should work to improve organization of the value chain to leverage the potential for more local value creation. Strategic partnerships among actors-e.g., in the form of values-based supply chains-could help to scale up production, pool supply, and close gaps in the local value chain through joint investments in the lacking infrastructure, such as preprocessing facilities. In order to bring more local vegetables into school catering, it is particularly important to find suitable organizational structures to coordinate the value chain in a way that makes local organic vegetable production for processing in large-scale kitchens financially viable for all participants, especially farmers.

Further research is needed on how local sourcing and aspects of values-based agri-food chains can be considered as criteria in sustainable public procurement processes. For example, it may be beneficial to investigate whether local values-based supply chains exist in the context of school catering procurement in other European regions, and how they are implemented. Structuration theory could provide a theoretical lens to study the processes in developing local organic value chains, to identify 
changes in actors' practices over time, and investigate how these practices are affected by value chain coordination activities.

Author Contributions: Conceptualization, C.L.B.; methodology, C.L.B., M.R., and V.B.; Formal analysis, C.L.B.; Investigation, C.L.B.; Data curation, C.L.B., M.R.; Writing—original draft preparation, C.L.B.; Writing-review and editing, M.R., V.B., and A.M.H.; Visualization, C.L.B.; Supervision, M.R., V.B., and A.M.H.; Research project administration, C.L.B.; Funding acquisition, C.L.B. and A.M.H.

Funding: Research for this paper has been conducted within the project "Regionales Bio-Gemüse aus Brandenburg" (Local Organic Vegetables from Brandenburg) which is funded by the European Agricultural Fund for Rural Development (EAFRD) in the framework of the European Innovation Partnership (EIP-Agri) and by funds from the State of Brandenburg. This work was also supported by the German Research Foundation (DFG) and the Technical University of Munich (TUM) in the framework of the Open Access Publishing Program.

Acknowledgments: The authors would like to thank the interviewees for providing valuable insight into their work practices and perspectives. Many thanks to Evelyn Juister and the rest of the project team "Regionales Bio-Gemüse aus Brandenburg" that inspired this research and made it possible.

Conflicts of Interest: The authors declare no conflict of interest.

\section{References}

1. Løes, A.K.; Nölting, B. Increasing organic consumption through school meals-Lessons learned in the iPOPY project. Org. Agric. 2011, 1, 91-110. [CrossRef]

2. Neto, B.; Caldas, M.G. The use of green criteria in the public procurement of food products and catering services: A review of EU schemes. Environ. Dev. Sustain. 2017, 20, 1-29. [CrossRef]

3. European Commission. Buying Green! A Handbook on Environmental Public Procurement. Available online: http:/ / ec.europa.eu/environment/gpp/pdf/Buying-Green-Handbook-3rd-Edition.pdf (accessed on 13 August 2018).

4. Smith, J.; Andersson, G.; Gourlay, R.; Karner, S.; Mikkelsen, B.E.; Sonnino, R.; Barling, D. Balancing competing policy demands: The case of sustainable public sector food procurement. J. Clean. Prod. 2016, 112, 249-256. [CrossRef]

5. Goggins, G.; Rau, H. Beyond calorie counting: Assessing the sustainability of food provided for public consumption. J. Clean Prod. 2016, 112, 257-266. [CrossRef]

6. Morgan, K.; Sonnino, R. Empowering consumers: The creative procurement of school meals in Italy and the UK. Int. J. Consum. Stud. 2007, 31, 19-25. [CrossRef]

7. Kultusministerkonferenz Deutschland. Allgemeinbildende Schulen in Ganztagsform in den Ländern in der Bundesrepublik Deutschland, Bonn, Germany, 2017. Available online: https:/ / www.kmk.org/fileadmin/ Dateien/pdf/Statistik/Dokumentationen/GTS_2016_Tabwerk.xlsx (accessed on 8 November 2018).

8. Senatsverwaltung BJF (Bildung, Jugend und Familie). Neuordnung des schulischen Mittagessens an offenen und gebundenen Ganztagsgrundschulen sowie für Förderzentren im Land Berlin, Germany, 2017. Available online: http://www.vernetzungsstelle-berlin.de/fileadmin/user_upload/Handreichung_Vergabe_Mittagessen_in_der_Grundschule_2._ueberarbeitete_Fassung_2017.pdf (accessed on 13 August 2018).

9. Haack, M.; von Münchhausen, S.; Häring, A.M. Discrepancy between Theory and Practice: Procurement of Local and Organic Food in Public Catering Systems. IFSA Conference Proceedings 2016. Available online: https: / www.harper-adams.ac.uk/events/ifsa/papers/5/5.9\%20Haack.pdf (accessed on 13 August 2018).

10. Giddens, A. The Construction of Society. Outline of the Theory of Structuration; Polity Press: Cambridge, UK, 1984.

11. Stones, R. Structuration Theory; Palgrave Macmillan: New York, NY, USA, 2005.

12. Born, B.; Purcell, M. Avoiding the Local trap: Scale and Food Systems in Planning Research. J. Plan. Educ. Res. 2006, 26, 195-207. [CrossRef]

13. Sonnino, R. Escaping the Local Trap: Insights on Re-localization from School Food Reform. J. Environ. Policy Plan. 2010, 12, 23-40. [CrossRef]

14. Filippini, R.; De Noni, I.; Corsi, S.; Spigarolo, R.; Bocchi, S. Sustainable school food procurement: What factors do affect the introduction and the increase of organic food? Food Policy 2018, 76, 109-119. [CrossRef] 
15. Lehtinen, U. Sustainability and local food procurement: A case study of Finnish public catering. Br. Food J. 2012, 114, 1053-1071. [CrossRef]

16. Risku-Norja, H.; Løes, A.K. Organic food in food policy and in public catering: Lessons learned from Finland. Org. Agric. 2017, 7, 111-124. [CrossRef]

17. Peterson, H.C.; Wysocki, A.; Harsh, S.B. Strategic choice along the vertical coordination continuum. Int. Food Agribus. Manag. 2001, 4, 149-166. [CrossRef]

18. Allen, P.; Guthman, J. From "old school" to "farm-to-school": Neoliberalization from the ground up. Agric. Hum. Values 2006, 23, 401-415. [CrossRef]

19. Conner, D.S.; Izumi, B.T.; Liquori, T.; Hamm, M.W. Sustainable School Food Procurement in Large K-12 Districts: Prospects for Value Chain Partnerships. Agric. Resour. Econ. Rev. 2012, 41, 100-113. [CrossRef]

20. Feenstra, G.; Allen, P.; Hardesty, S.; Ohmart, J.; Perez, J. Using a supply chain analysis to assess the sustainability of farm-to-institution programs. J. Agric. Food Syst. Community Dev. 2011, 1, 69-84. [CrossRef]

21. Heiss, S.N.; Sevoian, N.K.; Conner, D.S.; Berlin, L. Farm to institution programs: Organizing practices that enable and constrain Vermont's alternative food supply chains. Agric. Hum. Values 2015, 32, 87-97. [CrossRef]

22. Marsden, T.; Banks, J.; Bristow, G. Food Supply Chain Approaches: Exploring their Role in Rural Development. Sociol. Rrural. 2000, 40, 424-438. [CrossRef]

23. Renting, H.; Marsden, T.K.; Banks, J. Understanding alternative food networks: Exploring the role of short food supply chains in rural development. Environ. Plan. A 2003, 35, 393-411. [CrossRef]

24. Stevenson, G.W.; Pirog, R. Values-based supply chains: Strategies for agrifood enterprises of the middle. In Food and the Mid-Level Farm: Renewing an Agriculture of the Middle; Lyson, T.A., Stevenson, G.W., Welsh, R., Eds.; The MIT Press: Cambridge, MA, USA, 2008; pp. 119-143.

25. Bloom, J.D.; Hinrichs, C.C. Moving local food through conventional food system infrastructure: Value chain framework comparisons and insights. Renew. Agric. Food Syst. 2011, 26, 13-23. [CrossRef]

26. Stevenson, G.W.; Clancy, K.; King, R.; Lev, L.; Ostrom, M.; Smith, S. Midscale food value chains: An introduction. J. Agric. Food Syst. Community Dev. 2011, 1, 27-34. [CrossRef]

27. Archer, M. Social Integration and System Integration: Developing the Distinction. Sociology 1996, 30, 679-699. [CrossRef]

28. Thompson, J.B. The Theory of Structuration. In Social Theory of Modern Societies: Anthony Giddens and His Critics; Held, D., Thompson, J.B., Eds.; Cambridge University Press: Cambridge, UK, 1989; pp. 56-76.

29. Sewell, W.H., Jr. A Theory of Structure: Duality, Agency, and Transformation. Am. J. Sociol. 1992, 98, 1-29. [CrossRef]

30. Den Hond, F.; Boersma, F.K.; Heres, L.; Kroes, E.H.; van Oirschot, E. Giddens à la Carte? Appraising empirical applications of Structuration Theory in management and organization studies. J. Political Power 2012, 5, 239-264. [CrossRef]

31. Orlikowski, W.J. The Duality of Technology: Rethinking the Concept of Technology in Organizations. Organ. Sci. 1992, 3, 398-427. [CrossRef]

32. Pozzebon, M.; Pinsonneault, A. Challenges in Conducting Empirical Work Using Structuration Theory: Learning from IT Research. Organ. Stud. 2005, 26, 1353-1376. [CrossRef]

33. Sydow, J.; Windeler, A. Organizing and Evaluating Interfirm Networks: A Structurationist Perspective on Network Processes and Effectiveness. Organ. Sci. 1998, 9, 265-284. [CrossRef]

34. Lewis, I.; Suchan, J. Structuration theory: Its potential impact on logistics research. Int. J. Phys. Distrib. Logist. Manag. 2003, 33, 296-315. [CrossRef]

35. Dillard, J.; Pullman, M. Cattle, Land, People, and Accountability Systems: The Makings of a Values-based Organisation. Soc. Environ. Account. J. 2017, 37, 33-58. [CrossRef]

36. Pullman, M.E.; Dillard, J. Values based supply chain management and emergent organizational structures. Int. J. Oper. Prod. Manag. 2010, 30, 744-771. [CrossRef]

37. Jarosz, L. Understanding agri-food networks as social relations. Agric. Hum. Values 2000, 17, $279-283$. [CrossRef]

38. Lockie, S.; Kitto, S. Beyond the Farm Gate: Production-Consumption Networks and Agri-food Research. Sociol. Rural. 2000, 40, 3-19. [CrossRef] 
39. Greenhalgh, T.; Stones, R. Theorising big IT programmes in healthcare: Strong structuration theory meets actor-network theory. Soc. Sci. Med. 2010, 70, 1285-1294. [CrossRef] [PubMed]

40. Mutch, A. Actors and Networks or Agents and Structures: Towards a Realist View of Information Systems. Organization 2002, 9, 477-496. [CrossRef]

41. Jack, L.; Kholeif, A. Introducing strong structuration theory for informing qualitative case studies in organization, management and accounting research. Qual. Res. Org. Manag. Int. J. 2007, 2, 208-225. [CrossRef]

42. Eisenhardt, K.M. Building Theories from Case Study Research. Acad. Manag. Rev. 1989, 14, 532-550. [CrossRef]

43. Yin, R.K. Case Study Research and Applications: Design and Methods, 6th ed.; SAGE Publications: Los Angeles, CA, USA, 2018.

44. Mugera, A.W.; Bitsch, V. Managing Labor on Dairy Farms: A Resource-based Perspective with Evidence from Case Studies. Int. Food Agribus. Manag. 2005, 8, 79-98.

45. Sterns, J.A.; Schweikhardt, D.B.; Peterson, H.C. Using Case Studies as an Approach for Conducting Agribusiness Research. Int. Food Agribus. Manag. 1998, 1, 311-327. [CrossRef]

46. Westgren, R.; Zering, K. Case Study Research Methods for Firm and Market Research. Agribus. Int. J. 1998, 14, 415-423. [CrossRef]

47. Patton, Q.M. Qualitative Research and Evaluation Methods: Integrating Theory and Practice, 4th ed.; SAGE Publications: Thousand Oaks, CA, USA, 2015.

48. Johnson, J.M. In-depth Interviewing. In Handbook of Interview Research: Context and Method; Gubrium, J., Holstein, J., Eds.; SAGE Publications: Thousand Oaks, CA, USA, 2002; pp. 103-119.

49. Bitsch, V.; Yakura, E.K. Middle Management in Agriculture: Roles, Functions, and Practices. Int. Food Agribus. Manag. 2007, 10, 1-28.

50. Warren, S. Visual Methods in Organizational Research. In The SAGE Handbook of Organizational Research Methods; Buchmann, D.A., Bryman, A., Eds.; SAGE Publications: Thousand Oaks, CA, USA, 2011; pp. 566-582.

51. Oliver, D.G.; Serovich, J.M.; Mason, T.L. Constraints and Opportunities with Interview Transcription: Towards Reflection in Qualitative Research. Soc. Forces 2005, 84, 1273-1289. [CrossRef] [PubMed]

52. Schreier, M. Qualitative Content Analysis in Practice; SAGE Publications: London, UK, 2012.

53. Friese, S. Qualitative Data Analysis with ATLAS.ti, 2nd ed.; SAGE Publications Ltd.: London, UK, 2014.

54. Kloppenburg, J.; Wubben, D.; Grunes, M. Linking the Land and the Lunchroom: Lessons from the Wisconsin Homegrown Lunch Project. J. Hunger Environ. Nutr. 2008, 3, 440-455. [CrossRef]

55. Izumi, B.T.; Wright, D.W.; Hamm, M.W. Farm to school programs: Exploring the role of regionally-based food distributors in alternative agrifood networks. Agric. Hum. Values 2010, 27, 335-350. [CrossRef]

56. AMI (Agrarmarkt Informations-Gesellschaft mbH). AMI Markt Bilanz Öko-Landbau 2017: Daten, Fakten, Entwicklungen, Deutschland, EU, Welt; AMI: Bonn, Germany, 2017.

57. Doernberg, A.; Zasada, I.; Bruszewska, K.; Skoczowski, B.; Piorr, A. Potentials and Limitations of Regional Organic Food Supply: A Qualitative Analysis of Two Food Chain Types in the Berlin Metropolitan Region. Sustainability 2016, 8, 1125. [CrossRef]

58. Schebesta, H. Revision of the EU Green Public Procurement Criteria for Food Procurement and Catering Services-Certification Schemes as the Main Determinant for Public Sustainable Food Purchases? Eur. J. Risk Regul. 2018, 9, 316-328. [CrossRef]

59. Post, A.; Shanahan, H.; Jonsson, L. Food processing: Barriers to, or opportunities for, organic foods in the catering sector? Br. Food J. 2008, 110, 160-173. [CrossRef]

60. Conner, D.S.; Abate, G.; Liquori, T.; Hamm, M.W.; Peterson, H.C. Prospects for More Healthful, Local, and Sustainably Produced Food in School Meals. J. Hunger Environ. Nutr. 2010, 5, 416-433. [CrossRef]

61. Mikkelsen, B.E.; Sylvest, J. Organic Foods on the Public Plate: Technical Challenge or Organizational Change? J. Food Bus. Res. 2012, 15, 64-83. [CrossRef] 
62. Conner, D.S.; Nowak, A.; Berkenkamp, J.; Feenstra, G.W.; Van Soelen Kim, J.; Liquori, T.; Hamm, M.W. Value Chains for Sustainable Procurement in Large School Districts: Fostering Partnerships. J. Agric. Food Syst. Community Dev. 2011, 1, 55-68. [CrossRef]

63. Regierender Bürgermeister von Berlin, Senatskanzlei. Koalitionsvereinbarung 2016-2021, Berlin, Germany, 2016. Available online: https://www.berlin.de/rbmskzl/regierender-buergermeister/senat/ koalitionsvereinbarung/ (accessed on 8 November 2018). 